\title{
Quantitative and qualitative analysis of microorganisms in root-filled teeth with persistent infection: Monitoring of the endodontic retreatment
}

\author{
Marcos S. Endo ${ }^{1}$, Caio C. R. Ferraz ${ }^{1}$, Alexandre A. Zaia ${ }^{1}$, Jose F. A. Almeida ${ }^{1}$, \\ Brenda P. F. A. Gomes ${ }^{1}$
}

Correspondence: Dr. Brenda PFA Gomes

Email: bpgomes@fop.unicamp.br

\begin{abstract}
'Department of Restorative Dentistry, Endodontics Division, Piracicaba Dental School - State University of Campinas - UNICAMP, Piracicaba, SP, Brazil
\end{abstract}

\section{ABSTRACT}

Objective: The aim of this study was to investigate in vivo microorganisms detected in root-filled teeth with post-treatment apical periodontitis and quantify colony-forming units (CFU) during endodontic retreatment. Materials and Methods: Fifteen root-filled teeth had their previous gutta-percha removed and were randomly instrumented before being divided into three groups and medicated with either $\left[\mathrm{Ca}(\mathrm{OH})_{2}+2 \% \mathrm{CHX}\right.$ gel], $\left[\mathrm{Ca}(\mathrm{OH})_{2}+0.9 \% \mathrm{NaCl}\right]$ or $2 \% \mathrm{CHX}$ gel. Samples were taken after removal of gutta-percha (S1), after chemomechanical preparation using 2\% CHX gel (S2), and after inter-appointment dressing (S3) for 7 or 14 days later. Cultivable bacteria recovered from infected root canals at the three stages were counted and identified by means of culture and PCR assay (16S rDNA). Quantitative data were statistically analyzed by using Mann-Whitney test in which pairs of groups were compared $(P<0.05)$. Results: CFU counts decreased significantly from S1 to S2 $(P<0.05)$. No significant difference was found between S2 and S3 $(P=0.3093)$ for all three experimental groups. Chemomechanical preparation and intra-canal dressing promoted significant median reductions of $99.61 \%$ and $99.57 \%$, respectively, in the number of bacteria compared to S1 samples. A total of 110 cultivable isolates were recovered by culture technique from 32 different species and 7 different genera. Out of the 13 target species-specific primer of bacteria analyzed, 11 were detected during endodontic retreatment. Conclusion: The great majority of taxa found in post-treatment samples were Gram-positive bacteria, although Gram-negative bacteria were found by molecular methods. Moreover, our results showed that gutta-percha removal and chemomechanical preparation are effective for root canal disinfection, whereas additional intra-canal dressing did not improve disinfection.

Key words: Endodontic failure, endodontic outcome, intra-canal dressing, nonsurgical retreatment, root canal infection

\section{INTRODUCTION}

Bacteria remaining within the root canal system are a significant factor in endodontic failures. One of the most important objectives of a successful treatment of apical periodontitis is to eliminate or reduce the presence of intra-canal bacteria. Thus, a negative culture before root canal-filling is related to long-term success in the root canal treatment. ${ }^{[1,2]}$

Numerous treatment strategies and regimens have been suggested for treatment of teeth with failed endodontic therapy. Management of post-treatment pathosis includes non-surgical retreatment and/or intra-canal dressing, apical surgery, or extraction and immediate implant placement. Often, non-surgical retreatment is the preferred choice because it is the least invasive approach. ${ }^{[3,4]}$

Studies have investigated the composition of microbial flora from canals with persistent apical lesions before endodontic retreatment by using culture technique ${ }^{[5-9]}$ and PCR assay (16s rDNA), ${ }^{[10,11]}$ but it is also important to reveal bacterial reduction and

\footnotetext{
How to cite this article: Endo MS, Ferraz CC, Zaia AA, Almeida JF, Gomes BP. Quantitative and qualitative analysis of microorganisms in root-filled teeth with persistent infection: Monitoring of the endodontic retreatment. Eur J Dent 2013;7:302-9. 
identify the taxa persisting after different clinical procedures, such as chemomechanical preparation and intra-canal dressing. Appropriate measures for control and prevention of infection are essential to maximize the success of the retreatment, including strict asepsis, complete chemomechanical preparation using antimicrobial irrigants, intra-canal dressing, adequate root canal-filling, and good coronal sealing.

Clinical follow-up studies have reported that intra-canal dressing between appointments enhanced microbial reduction. ${ }^{[12,13]}$ The ability of intra-canal dressing to eliminate bacterial species completely from the root-filled canal with post-treatment apical periodontitis has been questioned.

The aim of this study was to investigate in vivo microorganisms detected from root-filled teeth with post-treatment apical periodontitis and quantify colony-forming units (CFU) during different stages of endodontic retreatment.

\section{MATERIALS AND METHODS}

\section{Patient selection}

Fifteen patients were selected from those who attended the Piracicaba Dental School for non-surgical endodontic retreatment. The Human Volunteers Research and Ethics Committee of the Piracicaba Dental School approved a protocol (139/2008) describing the specimen collection for this investigation, and all patients signed an informed consent form to participate. A detailed medical and dental history was obtained from each patient. Patients who had received antibiotic treatment during the last 3 months or had a general disease were excluded from the study. The age of the patients ranged from 19 to 65 years old. All selected teeth had been previously root-filled and showed radiographic evidence of apical periodontitis. Failure of root canal treatment was determined on the basis of clinical and radiographic examinations. All teeth had been root canal treated more than 2 years earlier and the patients were asymptomatic. All teeth also had enough crown structure for adequate isolation with a rubber dam, and none of them showed presence of periodontal pockets deeper than $4 \mathrm{~mm}$.

\section{Microbial sampling}

The teeth were isolated with rubber dam, with crown and surroundings being disinfected with $30 \% \mathrm{H}_{2} \mathrm{O}_{2}(\mathrm{v} / \mathrm{v})$ for 30 seconds, followed by $2.5 \%$ $\mathrm{NaOCl}$ for an additional 30 seconds. Next, $5 \%$ sodium thiosulfate was used to inactivate the disinfectant agents. ${ }^{[9,14]}$ A swab sample was taken from the surface and streaked on blood agar plates to test for disinfection. An access cavity was prepared with sterile high-speed diamond burs under irrigation with sterile physiological solution. Before entering the pulp chamber, the access cavity was disinfected according to the same protocol as described above and sterility was checked again by taking a swab sample from the cavity surface and streaking it onto blood agar plates. Aseptic techniques were used throughout the root canal treatment and sample acquisition. The samples (pre- and post-clinical procedures) were collected with three sterile paper points, which were consecutively placed into each canal until reaching the total length calculated from the pre-operative radiograph. The paper points were kept in place for 60 seconds and then pooled in a sterile tube containing 1-mL VMGA III transport medium. ${ }^{[14]}$ The samples were transported to the microbiology laboratory within 15 minutes and placed in anerobic workstation (Don Whitley Scientific, Bradford, UK).

\section{Clinical procedures}

The same endodontic specialist performed all retreatments, including intra-canal dressing and sampling procedures. The tooth was anesthetized and after accessing the pulp chamber the root-filling materials were removed by using the crown-down technique. No solvent was used during the procedure, which prevented a negative effect on microbial viability. Bucco-lingual and mesio-distal radiographs of each tooth were taken to confirm removal of gutta-percha.

\section{First appointment}

The root-filling was removed by using Gates-Glidden drills (Dentsply Maillefer, Ballaigues, Switzerland) of sizes \#5 (1.3 mm), \#4 (1.1 mm), \#3 (0.9 mm), and \#2 $(0.7 \mathrm{~mm})$ until reaching a 6 - $\mathrm{mm}$ length, which was shorter than the working length and endodontic files. Irrigation with sterile physiological solution was performed in order to remove any remaining materials and to moisten the canal prior to sample collection. A K-file of size \#15 (Dentsply Maillefer) was placed into the full length of the root canal, which was calculated from pre-operative radiograph. This small file was taken to the patency. Working length (at apical foramen) was confirmed by apical locator (Novapex, Forum Technologies, Rishon le-Zion, Israel). After removal of the gutta-percha with hand files, the first sample was collected with three paper points and transported in VMGA III. The apical preparation was performed by using K-files ranging from size \#40 to \#45 followed by step back instrumentation, which ended after using three files larger than the last file used for apical preparation. 
All root canals were irrigated with a syringe (2-G needle) containing $1 \mathrm{~mL}$ of chemical auxiliary substance $(2 \%$ chlorhexidine gel; Itapetininga, SP, Brazil) before the use of each instrument and then immediately rinsed with $\mathrm{mL}$ of sterile physiological solution. The chlorhexidine gel (CHX) consisted of gel base ( $1 \%$ natrosol) and $\mathrm{CHX}$ gluconate at $\mathrm{pH}$ 7.0. Natrosol gel (hydroxyethyl cellulose) is a non-ionic, highly inert, and water-soluble agent. After instrumentation, CHX activity was inactivated with $5 \mathrm{~mL}$ of a solution containing $5 \%$ Tween 80 and $0.07 \%(\mathrm{w} / \mathrm{v})$ lecithin during 1-minute period, which was removed with $5 \mathrm{~mL}$ of sterile physiological solution. Retreatment was deemed complete when the last file reached the working length, with no filling material covering the instrument and canal walls being smooth and free of visible debris. Furthermore, a close inspection under high magnification with dental operating microscope (D F Vasconcelos S/A, São Paulo, Brazil) showed complete removal of gutta-percha.

After the root canal preparation was finished, the canal was irrigated with $17 \%$ EDTA $(5 \mathrm{~mL})$ for 3 minutes and then rinsed with $5 \mathrm{~mL}$ of sterile physiological solution. Next, the second sample (S2) was collected with three paper points and transported in VMGA III.

Fifteen root-filled teeth with persistent infection were divided randomly into three groups. Intra-canal dressings were put inside the canals as follows:

- Group $1(n=5)$ : $\mathrm{Ca}(\mathrm{OH})_{2}+2 \%$ chlorhexidine gel. Re-accessed after 14 days.

- Group $2(n=5): \mathrm{Ca}(\mathrm{OH})_{2}+$ sterile physiological solution $(0.9 \% \mathrm{NaCl})$. Re-accessed after 14 days.

- Group 3 ( $n=5)$ : 2\% chlorhexidine gel. Re-accessed after 7 days.

The canal was dried with paper points. A calcium hydroxide $\left[\mathrm{Ca}(\mathrm{OH})_{2}\right]$ paste was placed over the entire length of the prepared canal by using lentulo spiral fillers. The paste was packed at the level of the canal entrance and a radiograph was taken to check for adequate placement (homogeneous filling throughout the entire extension of the prepared canal). The access cavity was then temporized with temporary cement to a thickness of at least $2 \mathrm{~mm}$ (Coltosol, Coltène/ Whaledent, $\mathrm{OH}, \mathrm{USA}$ ) and a second layer of composite restoration (Filtek Z250; 3M ESPE, St. Paul, MN, USA) was applied in combination with a single bond adhesive (3M ESPE).

\section{Second appointment}

The second appointment was scheduled for 7 or 14 days later. At that time, the tooth was isolated with a rubber dam, the operative field was disinfected as previously performed at the first visit, and a control bacteriological sample was obtained from the operating field. Composite restoration and temporary cement were removed with a sterile high-speed carbide bur. In Group 1, the canal walls were cleaned with a hand K-file of size greater than that of the master apical file, irrigated with $5 \mathrm{~mL}$ of sterile physiological solution, dried with paper points, and irrigated with $5 \mathrm{~mL}$ of a solution containing $5 \%$ Tween 80 and $0.07 \%(\mathrm{w} / \mathrm{v})$ lecithin during 1-minute period to inactivate $\mathrm{CHX} .{ }^{[15]}$ In Group 2, the canal walls were cleaned with a hand K-file of size greater than that of the master apical file, irrigated with $5 \mathrm{~mL}$ of sterile physiological solution as in Group 1, and irrigated with $5 \mathrm{~mL}$ of a solution containing 5\% Tween 80 and $0.07 \%(\mathrm{w} / \mathrm{v})$ lecithin. In Group 3, canals were flushed with $5 \mathrm{~mL}$ of sterile physiological solution, dried with paper points, and irrigated with $5 \mathrm{~mL}$ of a solution containing $5 \%$ Tween 80 and $0.07 \%(\mathrm{w} / \mathrm{v})$ lecithin. The root canal walls were slightly filed to remove scattered calcium hydroxide remnants, and a post-medication sample (S3) was collected from the canals.

Finally, all teeth were filled with vertically and laterally compacted gutta-percha cones (Konne, Belo Horizonte, MG, Brazil) and Endométhasone sealer (Septodont, Saint-Maur-des-Fossés, France). Access cavities were restored with a thickness of at least $2 \mathrm{~mm}$ (Coltosol, Coltène/Whaledent) and a second layer of composite restoration (Filtek Z250;3M ESPE, St. Paul, MN, USA) was applied in combination with a single-bond adhesive.

\section{Microbial identification}

Microbial samples, isolation and speciation were performed by using advanced microbiological techniques for anerobic species. Inside the anerobic workstation, the tubes containing the transport medium were shaken in a mixer for 60 seconds (Agitador MA 162-Marconi, São Paulo, SP, Brazil). Serial 10-fold dilutions were made up to $1 / 10^{4}$ in pre-reduced Fastidious Anaerobe Broth (FAB, Lab M, Bury, UK) and $50 \mu \mathrm{L}$ of each serial dilution were plated onto several media as follows: $5 \%$ defibrinated sheep blood-FAA Agar (FAB) alone, and supplemented with $600 \mu \mathrm{L}$ of hemin and $600 \mu \mathrm{L}$ of menadione. The plates were incubated at $37^{\circ} \mathrm{C}$ in anerobic atmosphere for up to 14 days to permit detection of very slow-growing strains. The same dilutions were plated on $5 \%$ sheep blood Brain Heart Infusion (BHI) agar (Oxoid, Basingstoke, UK) to allow aerobic or facultative microorganisms, such as m-Enterococcus agar (Difco, Sparks, MD, 
USA), MacConkey agar (Difco), Mitis salivarius agar (Difco), and Agar Dextrose Sabouraud (Difco), to grow.

Preliminary characterization of microbial species was based on the features of their colonies (i.e., size, color, shape, height, rim, surface, texture, consistency, brightness, and hemolysis), visualized with stereoscopic lens (Lambda Let 2, Atto instruments Co., Hong Kong) at $\times 16$ magnification. Isolates were then purified by subculture, Gram-stained, tested for catalase production, and their gaseous requirements established by incubation for 2 days aerobically and anerobically. Based on this information, it was possible to select appropriate procedures for identification of the following species:

- Rapid ID 32 A (BioMérieux SA, Marcy-l'Etoile, France) for strict anerobic, Gram-negative or Gram-positive rods.

- API Staph (BioMérieux SA) for Staphylococci and micrococci (Gram-positive cocci; catalase-positive).

- API 20 Strep (BioMérieux SA) for Streptococci (Gram-positive cocci; catalase-negative).

- API 20 E (BioMérieux SA) for enterobacter (Gram-negative enteric rods; catalase-positive, oxidase-negative).

- API NH (BioMérieux SA) for Eikenella spp., Haemophilus spp., Neisseria spp. and Actinobacillus spp. (Gram-negative cocci and rods; facultative, oxidase-positive).

- API C AUX (BioMérieux SA) for yeast (Candida spp.).

\section{Bacterial detection (Polymerase chain reaction - PCR 16S rDNA)}

Reference bacteria strains used in this study were acquired from the American Type Culture Collection (ATCC) and are listed as follows:

Enterococcus faecalis (ATCC 4034), Filifactor alocis (ATCC 35896), Fusobacterium nucleatum (ATCC 25586), Gemella morbillorum (ATCC 27824), Parvimonas micra (ATCC 33270), Porphyromonas endodontalis (ATCC 35406), Porphyromonas gingivalis (ATCC 33277), Prevotella intermedia (ATCC 25611), Prevotella nigrescens (ATCC 33536), Prevotella tannerae (ATCC 51259), Tannerella forsythia (ATCC 43037), Treponema denticola (ATCC 35405), and Treponema socranskii (ATCC 35536).

\section{DNA extraction}

MicrobialDNA fromallstages of endodontic retreatment samples (S1, S2, and S3) and control sample, as well as from ATCC bacteria, were extracted and purified by using the QIAamp DNA Mini Kit (Qiagen, Hilden,
Germany) according to the manufacturer's instructions. The DNA concentration (absorbance at $260 \mathrm{~nm}$ ) was determined with a spectrophotometer (Nanodrop 2000; Thermo Scientific, Wilmington, DE, USA).

\section{PCR assay}

The PCR reaction was performed in a thermocycler (My-Cycler; Bio-Rad, Hercules, CA, USA) with total volume of $25 \mu \mathrm{L}$ containing $2.5 \mu \mathrm{L}$ of $10 \mathrm{X}$ Taq buffer (1x) (Invitrogen, Eugene, OR, USA), $0.5 \mu \mathrm{L}$ of dNTP mix $(25 \mu \mathrm{mol} / \mathrm{L}$ of each deoxyribonucleoside triphosphate - dATP, dCTP, dGTP, and dTTP) (Invitrogen), $1.25 \mu \mathrm{L}$ of $25 \mu \mathrm{mol} / \mathrm{L} \mathrm{MgCl} 2$, $0.25 \mu \mathrm{L}$ of forward and reversal universal primers $(0.2 \mu \mathrm{mol} / \mathrm{L})$ (Invitrogen), $1.5 \mu \mathrm{L}$ of sample DNA $(1 \mu \mathrm{g} /$ $50 \mu \mathrm{L}), 1.5 \mu \mathrm{L}$ of Taq DNA polymerase (1 U) (Invitrogen), and $17.25 \mu \mathrm{L}$ of nuclease-free water. The primer sequences and PCR cycling parameters were previously optimized $^{[16]}$ and are listed in Table 1.

\section{Statistical analysis}

Effectiveness of each treatment step in rendering root canals free of cultivable bacteria was recorded as percentage of cases yielding negative cultures. In this regard, the one-tailed Fisher exact test was used to compare $\mathrm{S} 2$ and $\mathrm{S} 3$ samples. The percent reduction in the number of CFUs after each treatment step was calculated based on quantitative data obtained from samples S1, S2, and S3. Quantitative data were statistically analyzed for differences by using the Mann-Whitney $U$ test comparing pairs of groups. Significance level was always set at $5 \%(P<0.05)$.

\section{RESULTS}

All disinfection control samples yielded no growth, confirming effective disinfection of the tooth surfaces by culture and PCR technique (16s rDNA).

\section{Colony-forming unit}

The bacterial counting at each stage of retreatment is shown in Table 2. High bacterial counting was found in all S1 samples. With regard to the cultures obtained after removal of the root canal-filling material (S1), 15/15 root-filled canal (100\%) contained cultivable microorganisms. Of these, the quantity of microorganisms recovered ranged from 20 to $1.7 \times 10^{5} \mathrm{CFU} / \mathrm{mL}$ (with median of $5.14 \times 10^{3}$ $\mathrm{CFU} / \mathrm{mL}$ ). After chemomechanical preparation with 2\% CHX gel (S2), it was found a reduction in $99.61 \% \mathrm{CFU} / \mathrm{mL}$. Ten cases presented microbial growth ranging from 0 to $1.96 \times 10^{3} \mathrm{CFU} / \mathrm{mL}$ (with median of $20 \mathrm{CFU} / \mathrm{mL}$ ) and 5 canals $(33 \%)$ showed no microbial growth. At the beginning of the second 
Endo, et al.: Microbiological monitoring of the endodontic retreatment

\begin{tabular}{|c|c|c|c|}
\hline $\begin{array}{l}\text { Target } \\
\text { bacteria }\end{array}$ & Primer pairs $\left(5^{\prime}-3^{\prime}\right)$ & $\begin{array}{l}\text { Amplicon } \\
\text { size }\end{array}$ & Cycles \\
\hline $\begin{array}{l}\text { Universal } \\
\text { (16S rDNA) }\end{array}$ & $\begin{array}{l}\text { Forward: TCC TAC GGG AGG CAG CAG T/ } \\
\text { Reverse: GGA CTA CCA GGG TAT CTAATC CTG } \\
\text { TT }\end{array}$ & $466 \mathrm{bp}$ & $\begin{array}{l}\text { Initial denaturation at } 95^{\circ} \mathrm{C} \text { for } 10 \mathrm{~min} \text { and } \\
40 \text { cycles of } 95^{\circ} \mathrm{C} \text { for } 10 \mathrm{~s}, 60^{\circ} \mathrm{C} \text { for } 10 \mathrm{~s} \text {, } \\
\text { and a final extension step at } 72^{\circ} \mathrm{C} \text { for } 25 \mathrm{~s}\end{array}$ \\
\hline $\begin{array}{l}\text { Enterococcus } \\
\text { faecalis }\end{array}$ & $\begin{array}{l}\text { Forward: CCG AGT GCT TGC ACT CAA TTG G/ } \\
\text { Reverse: CTC TTA TGC CAT GCG GCA TAAAC }\end{array}$ & $138 \mathrm{bp}$ & $\begin{array}{l}\text { Initial denaturation at } 95^{\circ} \mathrm{C} \text { for } 2 \text { min and } \\
36 \text { cycles of } 95^{\circ} \mathrm{C} \text { for } 1 \mathrm{~min}, 57^{\circ} \mathrm{C} \text { for } 1 \mathrm{~min} \text {, } \\
72^{\circ} \mathrm{C} \text { for } 1 \mathrm{~min} \text {, and a final step } 72^{\circ} \mathrm{C} \text { for } 7 \text { min }\end{array}$ \\
\hline Filifactor alocis & $\begin{array}{l}\text { Forward: CAG GTG GTT TAA CAA GTT AGT GG/ } \\
\text { Reverse: CTA AGT TGT CCT TAG CTG TCT CG }\end{array}$ & $594 \mathrm{bp}$ & $\begin{array}{l}\text { Initial denaturation at } 95^{\circ} \mathrm{C} \text { for } 2 \mathrm{~min} \text { and } \\
26 \text { cycles of } 95^{\circ} \mathrm{C} \text { for } 30 \mathrm{~s}, 58^{\circ} \mathrm{C} \text { for } 1 \mathrm{~min}, 72^{\circ} \mathrm{C} \\
\text { for } 1 \mathrm{~min} \text {, and a final step } 72^{\circ} \mathrm{C} \text { for } 2 \mathrm{~min}\end{array}$ \\
\hline $\begin{array}{l}\text { Fusobacterium } \\
\text { nucleatum }\end{array}$ & $\begin{array}{l}\text { Forward: AGT AGC ACA AGG GAG ATG TAT G/ } \\
\text { Reverse: CAA GAA CTA CAA TAG AAC CTG A }\end{array}$ & $1000 \mathrm{bp}$ & $\begin{array}{l}\text { Initial denaturation at } 95^{\circ} \mathrm{C} \text { for } 5 \mathrm{~min} \text { and } \\
30 \text { cycles of } 94^{\circ} \mathrm{C} \text { for } 30 \mathrm{~s}, 40^{\circ} \mathrm{C} \text { for } 1 \mathrm{~min}, 72^{\circ} \mathrm{C} \\
\text { for } 2 \mathrm{~min} \text {, and a final step } 72^{\circ} \mathrm{C} \text { for } 10 \mathrm{~min}\end{array}$ \\
\hline $\begin{array}{l}\text { Gemella } \\
\text { morbillorum }\end{array}$ & $\begin{array}{l}\text { Forward: GAC TAC CAG GGT ATC TAA TCC/ } \\
\text { Reverse: TAT GAG GTT GGC TGA CTC TCG }\end{array}$ & $781 \mathrm{bp}$ & $\begin{array}{l}\text { Initial denaturation at } 95^{\circ} \mathrm{C} \text { for } 2 \mathrm{~min} \text { and } \\
36 \text { cycles of } 94^{\circ} \mathrm{C} \text { for } 30 \mathrm{~s}, 52^{\circ} \mathrm{C} \text { for } 1 \mathrm{~min}, 72^{\circ} \mathrm{C} \\
\text { for } 2 \mathrm{~min} \text {, and a final step } 72^{\circ} \mathrm{C} \text { for } 10 \mathrm{~min}\end{array}$ \\
\hline $\begin{array}{l}\text { Prevotella } \\
\text { intemedia }\end{array}$ & $\begin{array}{l}\text { Forward: TTT GTT GGG GAG TAA AGC GGG/ } \\
\text { Reverse: TCA ACA TCT CTG TAT CCT GCG T }\end{array}$ & $575 \mathrm{bp}$ & $\begin{array}{l}\text { Initial denaturation at } 95^{\circ} \mathrm{C} \text { for } 2 \text { min and } \\
36 \text { cycles of } 94^{\circ} \mathrm{C} \text { for } 30 \mathrm{~s}, 58^{\circ} \mathrm{C} \text { for } 1 \mathrm{~min}, 72^{\circ} \mathrm{C} \\
\text { for } 2 \mathrm{~min} \text {, and a final step } 72^{\circ} \mathrm{C} \text { for } 10 \mathrm{~min}\end{array}$ \\
\hline $\begin{array}{l}\text { Prevotella } \\
\text { nigrescens }\end{array}$ & $\begin{array}{l}\text { Forward: ATG AAA CAAAGG TTT TCC GGT AAG/ } \\
\text { Reverse: CCC ACG TCT CTG TGG GCT GCG A }\end{array}$ & 804 bp & $\begin{array}{l}\text { Initial denaturation at } 95^{\circ} \mathrm{C} \text { for } 2 \mathrm{~min} \text { and } \\
36 \text { cycles of } 94^{\circ} \mathrm{C} \text { for } 30 \mathrm{~s}, 58^{\circ} \mathrm{C} \text { for } 1 \mathrm{~min}, 72^{\circ} \mathrm{C} \\
\text { for } 2 \mathrm{~min} \text {, and a final step } 72^{\circ} \mathrm{C} \text { for } 10 \mathrm{~min}\end{array}$ \\
\hline $\begin{array}{l}\text { Prevotella } \\
\text { tannerae }\end{array}$ & $\begin{array}{l}\text { Forward: CTT AGC TTG CTA AGT ATG CCG/ } \\
\text { Reverse: CAG CTG ACT TAT ACT CCC G }\end{array}$ & $550 \mathrm{bp}$ & $\begin{array}{l}\text { Initial denaturation at } 95^{\circ} \mathrm{C} \text { for } 2 \text { min and } \\
36 \text { cycles of } 94^{\circ} \mathrm{C} \text { for } 30 \mathrm{~s}, 55^{\circ} \mathrm{C} \text { for } 1 \mathrm{~min}, 72^{\circ} \mathrm{C} \\
\text { for } 2 \mathrm{~min} \text {, and a final step } 72^{\circ} \mathrm{C} \text { for } 10 \mathrm{~min}\end{array}$ \\
\hline $\begin{array}{l}\text { Tannerella } \\
\text { forsythia }\end{array}$ & $\begin{array}{l}\text { Forward: GCG TAT GTA ACC TGC CCG CA/ } \\
\text { Reverse: TGC TTC AGT GTC AGT TAT ACC T }\end{array}$ & $641 \mathrm{bp}$ & $\begin{array}{l}\text { Initial denaturation at } 95^{\circ} \mathrm{C} \text { for } 1 \mathrm{~min} \text { and } \\
36 \text { cycles of } 95^{\circ} \mathrm{C} \text { for } 30 \mathrm{~s}, 60^{\circ} \mathrm{C} \text { for } 1 \mathrm{~min}, 72^{\circ} \mathrm{C} \\
\text { for } 1 \mathrm{~min} \text {, and a final step } 72^{\circ} \mathrm{C} \text { for } 2 \mathrm{~min}\end{array}$ \\
\hline $\begin{array}{l}\text { Treponema } \\
\text { denticola }\end{array}$ & $\begin{array}{l}\text { Forward: TAA TAC CGAATG TGC TCA TTTACAT/ } \\
\text { Reverse: TCAAAGAAGCAT TCC CTC TTC TTC } \\
\text { TTA }\end{array}$ & $316 \mathrm{bp}$ & $\begin{array}{l}\text { Initial denaturation at } 95^{\circ} \mathrm{C} \text { for } 2 \text { min and } \\
36 \text { cycles of } 94^{\circ} \mathrm{C} \text { for } 30 \mathrm{~s}, 60^{\circ} \mathrm{C} \text { for } 1 \mathrm{~min}, 72^{\circ} \mathrm{C} \\
\text { for } 2 \mathrm{~min} \text {, and a final step } 72^{\circ} \mathrm{C} \text { for } 10 \mathrm{~min}\end{array}$ \\
\hline $\begin{array}{l}\text { Treponema } \\
\text { socranskii }\end{array}$ & $\begin{array}{l}\text { Forward: GAT CAC TGTATA CGGAAGGTAGACA/ } \\
\text { Reverse: TAC ACT TAT TCC TCG GAC AG }\end{array}$ & $288 \mathrm{bp}$ & $\begin{array}{l}\text { Initial denaturation at } 95^{\circ} \mathrm{C} \text { for } 2 \text { min and } \\
36 \text { cycles of } 94^{\circ} \mathrm{C} \text { for } 30 \mathrm{~s}, 56^{\circ} \mathrm{C} \text { for } 1 \mathrm{~min}, 72^{\circ} \mathrm{C} \\
\text { for } 2 \mathrm{~min} \text {, and a final step } 72^{\circ} \mathrm{C} \text { for } 10 \mathrm{~min}\end{array}$ \\
\hline $\begin{array}{l}\text { Parvimonas } \\
\text { micra }\end{array}$ & $\begin{array}{l}\text { Forward: AGA GTT TGA TCC TGG CTC AG/ } \\
\text { Reverse: ATA TCA TGC GAT TCT GTG GTC TC }\end{array}$ & $207 \mathrm{bp}$ & $\begin{array}{l}\text { Initial denaturation at } 95^{\circ} \mathrm{C} \text { for } 2 \mathrm{~min} \text { and } \\
36 \text { cycles of } 94^{\circ} \mathrm{C} \text { for } 30 \mathrm{~s}, 60^{\circ} \mathrm{C} \text { for } 1 \mathrm{~min}, 72^{\circ} \mathrm{C} \\
\text { for } 2 \mathrm{~min} \text {, and a final step } 72^{\circ} \mathrm{C} \text { for } 10 \mathrm{~min}\end{array}$ \\
\hline $\begin{array}{l}\text { Porphyromonas } \\
\text { endodontalis }\end{array}$ & $\begin{array}{l}\text { Forward: GCT GCA GCT CAA CTG TAG TC/ } \\
\text { Reverse: CCG CTT CAT GTC ACC ATG TC }\end{array}$ & 672 bp & $\begin{array}{l}\text { Initial denaturation at } 95^{\circ} \mathrm{C} \text { for } 2 \text { min and } \\
36 \text { cycles of } 94^{\circ} \mathrm{C} \text { for } 30 \mathrm{~s}, 58^{\circ} \mathrm{C} \text { for } 1 \mathrm{~min}, 72^{\circ} \mathrm{C} \\
\text { for } 2 \mathrm{~min} \text {, and a final step } 72^{\circ} \mathrm{C} \text { for } 10 \mathrm{~min}\end{array}$ \\
\hline $\begin{array}{l}\text { Porphyromonas } \\
\text { gingivalis }\end{array}$ & $\begin{array}{l}\text { Forward: AGG CAG CTT GCC ATA CTG CG/ } \\
\text { Reverse: ACT GTT AGC AAC TAC CGA TGT }\end{array}$ & 404 bp & $\begin{array}{l}\text { Initial denaturation at } 95^{\circ} \mathrm{C} \text { for } 2 \mathrm{~min} \text { and } \\
36 \text { cycles of } 94^{\circ} \mathrm{C} \text { for } 30 \mathrm{~s}, 60^{\circ} \mathrm{C} \text { for } 1 \mathrm{~min}, 72^{\circ} \mathrm{C} \\
\text { for } 2 \mathrm{~min} \text {, and a final step } 72^{\circ} \mathrm{C} \text { for } 2 \mathrm{~min}\end{array}$ \\
\hline
\end{tabular}

appointment (S3), cultures of 11 teeth were positives, ranging from 0 to $1.01 \times 10^{4} \mathrm{CFU} / \mathrm{mL}$ (with median of $40 \mathrm{CFU} / \mathrm{mL}$ ). When compared to $\mathrm{S1}$, a reduction of $99.57 \%$ was detected in S3. The counts in both samples S2 and S3 were significantly lower $(P<0.05)$ than that in S1. The differences between S2 and S3 counts were not significant $(P>0.05)$ for all cases.

After intra-canal dressing (S3), counts in Group 1 $\left[\mathrm{Ca}(\mathrm{OH})_{2}+2 \% \mathrm{CHX}\right.$ gel] were median reduced by $99.86 \%$, in Group 2 by $99.6 \%\left[\mathrm{Ca}(\mathrm{OH})_{2}+0.9 \%\right.$ $\mathrm{NaCl}$, and in Group 3 (2\% CHX gel) by $99.57 \%$. The differences between S2 and S3 counts were not significant $(P>0.05)$ in Groups 1,2 , and 3. Four canals presented with no microbial growth.

\section{Culture technique}

A total of 110 cultivable isolates belonging to 32 different species and 7 genera [Table 2] were recovered from the 15 root-filled canals examined after removal of the root-filling material (S1) (72 isolates), after chemomechanical preparation (S2) (16 isolates) and after intra-canal dressing (S3) (22 isolates), with the predominance of Gram-positive microorganisms. 


\begin{tabular}{|c|c|c|c|c|c|c|}
\hline \multirow[t]{2}{*}{ Microbial isolates } & \multicolumn{2}{|c|}{ s1 } & \multicolumn{2}{|c|}{ S2 } & \multicolumn{2}{|c|}{ S3 } \\
\hline & $\begin{array}{l}\text { Number of } \\
\text { root canals }\end{array}$ & $\begin{array}{l}\text { Percentage of } \\
\text { root canals }\end{array}$ & $\begin{array}{l}\text { Number of } \\
\text { root canals }\end{array}$ & $\begin{array}{l}\text { Percentage of } \\
\text { root canals }\end{array}$ & $\begin{array}{l}\text { Number of } \\
\text { root canals }\end{array}$ & $\begin{array}{l}\text { Percentage of } \\
\text { root canals }\end{array}$ \\
\hline Actinomyces israelii & 3 & 20.0 & - & - & 1 & 6.7 \\
\hline Actinomyces meyeri & - & - & - & - & 1 & 6.7 \\
\hline Actinomyces naeslundii & 3 & 20.0 & - & - & 1 & 6.7 \\
\hline Actinomyces odontolyticus & 2 & 13.3 & - & - & - & - \\
\hline Actinomyces viscosus & 1 & 6.7 & - & - & 2 & 13.3 \\
\hline Aerococcus viridans & 2 & 13.3 & 1 & 6.7 & 2 & 13.3 \\
\hline Bacteroides ureolyticus & - & - & - & - & 1 & 6.7 \\
\hline Bifidobacterium spp. & 3 & 20.0 & - & - & 1 & 6.7 \\
\hline Candida albicans & 3 & 20.0 & - & - & - & - \\
\hline Capnocytophaga spp. & - & - & 1 & 6.7 & - & - \\
\hline Clostridium bifermentans & 2 & 13.3 & - & - & - & - \\
\hline Clostridium clostridioforme & 1 & 6.7 & - & - & - & - \\
\hline Clostridium sporogenes & 1 & 6.7 & - & - & - & - \\
\hline Clostridium spp. & 1 & 6.7 & - & - & - & - \\
\hline Eggerthella lenta & 1 & 6.7 & 2 & 13.3 & - & - \\
\hline Enterococcus faecalis & 4 & 20.0 & 2 & 13.3 & 2 & 13.3 \\
\hline Gemella haemolysans & 3 & 20.0 & - & - & - & - \\
\hline Gemella morbillorum & 7 & 46.7 & 1 & 6.7 & 1 & 6.7 \\
\hline Haemophilus aphrophilus & 6 & 40.0 & 3 & 20.0 & 1 & 6.7 \\
\hline Lactococcus lactis cremoris & - & - & - & - & 1 & 6.7 \\
\hline Micrococcus spp. & 3 & 20.0 & 1 & 6.7 & - & - \\
\hline Moraxella catarrhalis & 1 & 6.7 & - & - & - & - \\
\hline Neisseria cinerea & 1 & 6.7 & - & - & - & - \\
\hline Neisseria spp. & 5 & 33.3 & 2 & 13.3 & 1 & 6.7 \\
\hline Prevotella oralis & - & - & - & - & 1 & 6.7 \\
\hline Propionibacterium propionicus & 2 & 13.3 & 1 & 6.7 & 1 & 6.7 \\
\hline Shigella spp. & - & - & - & - & 1 & 6.7 \\
\hline Staphylococcus aureus & 1 & 6.7 & - & - & 1 & 6.7 \\
\hline Staphylococcus chromogenes & 1 & 6.7 & - & - & - & - \\
\hline Staphylococcus epidermidis & 2 & 13.3 & 1 & 6.7 & - & - \\
\hline Staphylococcus hominis & 1 & 6.7 & - & - & - & - \\
\hline Staphylococcus lentus & 3 & 20.0 & - & - & 1 & 6.7 \\
\hline Staphylococcus xylosus & 3 & 20.0 & - & - & 1 & 6.7 \\
\hline Streptococcus constellatus & 2 & 13.3 & - & - & - & - \\
\hline Streptococcus mitis & - & - & 1 & 6.7 & 1 & 6.7 \\
\hline Streptococcus mutans & 1 & 6.7 & - & - & - & - \\
\hline Streptococcus oralis & 1 & 6.7 & - & - & - & - \\
\hline Streptococcus sanguis & 1 & 6.7 & - & - & - & - \\
\hline Veillonella spp. & 1 & 6.7 & - & - & - & - \\
\hline Total number of isolates & 72 & & 16 & & 22 & \\
\hline
\end{tabular}

The bacterial genera most frequently recovered from the root canals were: Staphylococcus spp. (13.63\%), Actinomyces spp (12.72\%), Gemella spp. (10.9\%), Haemophilus spp. (9.09\%) and Enterococcus spp. (7.27\%).

\section{Polymerase chain reaction}

All cases examined in this investigation harbored bacteria, which was evident by the results using universal 16S rDNA primers. A total of 69 bacteria were detected from the 15 root-filled canals examined after removal of the root-filling material (S1) $(n=29)$, after chemomechanical preparation (S2) $(n=12)$, and after intra-canal dressing (S3) $(n=28)$. The most commonly species detected were: Parvimonas micra $(24 \%)$, Prevotella nigrescens (14.67\%), Enterococcus faecalis $(13.33 \%)$, and Gemella morbillorum (12\%). Porphyromonas gingivalis and Filifactor alocis were not detected in any samples. 


\section{DISCUSSION}

Culture procedures have traditionally been used in the assessment of the microbiota associated with infections of endodontic origin..$^{[5-9]}$ Phenotype-based procedures for bacterial identification however; have some drawbacks that can result in underestimation of the microorganisms living in a given ecosystem. ${ }^{[17]}$ Furthermore, it is difficult to simulate the environmental conditions required for cultivation of fastidious microorganisms. Polymerase chain reaction (PCR 16s rDNA) method is more specific, accurate, sensitive and rapid than the culture technique, allowing uncultivable and fastidious microorganisms to be detected. ${ }^{[17]}$ Nevertheless, PCR cannot determine whether target DNA comes from live or dead bacteria. ${ }^{[18]}$

This study revealed by culture technique, the presence of predominantly facultative anaerobes and Gram-positive species and how they relate with the different phases of the endodontic treatment (S1, S2, S3), showing a heterogeneous profile of polymicrobial infection. The use of PCR enabled us to detect some Gram-negative bacteria species that are difficult to grow, such as the genera Fusobacterium spp., Porphyromonas spp., Prevotella spp., Tannerella spp. and Treponema spp. Furthermore, their prevalence was much more pronounced with the use of PCR, differently from those studies using only culture techniques, ${ }^{[5-9]}$ agreeing with the literature. ${ }^{[10,11]}$

Obtaining a representative sample of root-filled canals is not an easy task because of the limitations imposed by the physical constraints of the root canal and the presence of the root-filling material itself. ${ }^{[10,17]}$ In some cases, a negative culture result does not necessarily imply a bacteria-free root canal system, as microorganisms may be retained in complex areas of the system, embedded within a biofilm or exist in low numbers, thus being inaccessible to paper points used for sampling. ${ }^{[18]}$ Furthermore, microorganisms adhered to gutta-percha can be taken away after removal of the root canal-filling, and thus the CFU count may be underestimated. Even so, in this work, all teeth harbored microorganisms at $\mathrm{S1}$, which were identified by culture techniques and detected by PCR.

The main reason for a failure of the root canal therapy is the presence of persistent microorganisms after therapy or re-contamination of the canal system because of an inadequate seal. The clinical procedures require removal of the original root canal-filling, further instrumentation, disinfection and refilling. ${ }^{[4]}$ Complete elimination and/or reduction of the microorganisms in teeth with persistent infection is the main objective of the root canal retreatment. Residual organisms are likely to play a role in treatment failures. ${ }^{[5-6]}$ Clinical follow-up studies have reported that chemomechanical procedures reduce microorganisms in the root canal system, ${ }^{[12,19]}$ agreeing with the findings of the present study.

After the first appointment, restoration was placed by using definitive composite in combination with an adhesive in order to prevent re-infection of the root canal. Our results showed that even using a crown-down technique with 2\% CHX gel, apical patency and foramen enlargement, only $33.3 \%(5 / 15)$ of the canals were rendered bacteria-free after chemomechanical preparation. Some authors stated that $\mathrm{Ca}(\mathrm{OH})_{2}$ is necessary to kill bacteria remaining in the root canals. ${ }^{[12,20-23]}$ However, in the present study the CFU count increased in $7 / 15$ canals $(46.67 \%$ of the cases) after inserting the intra-canal dressing, a finding corroborated by some authors. ${ }^{[19,24,25]}$ On the other hand, in a clinical study, Siqueira et al. ${ }^{[26]}$ and Zerella et al. ${ }^{[27]}$ showed that the application of a intra-canal dressing with $\mathrm{Ca}(\mathrm{OH})_{2} / \mathrm{CHX}$ can increase the number of root canals yielding negative cultures. It is worth highlighting that a low number of bacteria (under the detection limit by culturing) still might reside in dentinal tubules and/or anastomosing systems after the use of the intra-canal dressing, being impossible to soak them up by the paper points. Nevertheless, these bacteria can rapidly multiply over a 2-week period of $\mathrm{Ca}(\mathrm{OH})_{2}$ dressing, enabling them to be further detected.

Ideally, single-visit root canal treatment is desirable if root canal disinfection can be achieved. ${ }^{[24]}$ Based on the currently available evidence, single-visit root canal treatment appeared to be slightly more effective than multiple visits, i.e. a $6.3 \%$ higher healing rate. However, the difference in healing rate between these two treatment regimens is not statistically significant. ${ }^{[19,24,28]}$ Our results showed that each group of intra-canal dressing $\left[\mathrm{Ca}(\mathrm{OH})_{2}+2 \%\right.$ $\mathrm{CHX}$ gel, $\mathrm{Ca}(\mathrm{OH})_{2}+0.9 \% \mathrm{NaCl}$, and $2 \% \mathrm{CHX}$ gel] did not significantly improve the disinfection, which is in agreement with Manzur et al., ${ }^{[29]}$ who had already observed that in cases with necrotic pulp. Saber and El-Hady ${ }^{[30]}$ demonstrated that all chemomechanical agents used were significantly better than calcium hydroxide in the elimination of biofilm bacteria. Despite this, intra-canal dressing showed antimicrobial activity against endodontic pathogens, as seen in an ex vivo study. ${ }^{[31]}$ Although intra-canal dressing does not significantly improve the bacteria reduction in the 
root canals, calcium hydroxide should be indicated in cases of lack of time to finish the endodontic retreatment in the first appointment, persistent pain and inflammatory exudates. It should be also remembered that when root canals are left empty between appointments, ${ }^{[12]}$ they can be recontaminated.

\section{CONCLUSIONS}

Thegreatmajority of taxa found in post-treatmentsamples were Gram-positive bacteria, although Gram-negative bacteria were found by molecular methods. Moreover, our results showed that gutta-percha removal and chemomechanical preparation with $2 \% \mathrm{CHX}$ gel, an effective root canal disinfectant, are effective for root canal disinfection, whereas additional intra-canal dressing did not improve disinfection.

\section{ACKNOWLEDGMENTS}

This work was supported by the Brazilian agencies FAPESP (11/50510-0; 11/50051-5) and CNPq (302575/2009-0). The authors deny any conflicts of interest.

\section{REFERENCES}

1. Byström A, Happonen RP, Sjögren U, Sundqvist G. Healing of periapical lesions of pulpless teeth after endodontic treatment with controlled asepsis. Endod Dent Traumatol 1987;3:58-63.

2. Sjögren U, Figdor D, Persson S, Sundqvist G. Influence of infection at the time of root filling on the outcome of endodontic treatment of teeth with apical peridontitis. Int Endod J 1997;30:297-306.

3. Siqueira JF Jr. Aetiology of root canal treatment failure: Why well-treated teeth can fail. Int Endod J 2001;34:1-10.

4. Salehrabi R, Rotstein I. Epidemiologic evaluation of the outcomes of orthograde endodontic retreatment. J Endod 2010;36:790-2.

5. Sundqvist G, Figdor D, Persson S, Sjögren U. Microbiologic analysis of teeth with failed endodontic treatment and the outcome of conservative re-treatment. Oral Surg Oral Med Oral Pathol Oral Radiol Endod 1998;85:86-93.

6. Molander A, Reit C, Dahlén G, Kvist T. Microbiological status of root-filled teeth with apical periodontitis. Int Endod J 1998;31:1-7.

7. Hancock $\mathrm{HH}^{\text {rd }}$, Sigurdsson A, Trope M, Moiseiwitsch J. Bacteria isolated after unsuccessful endodontic treatment in a north american population. Oral Surg Oral Med Oral Pathol Oral Radiol Endod 2001;91:579-86.

8. Pinheiro ET, Gomes BP, Ferraz CC, Teixeira FB, Zaia AA, Souza Filho FJ. Evaluation of root canal microorganisms isolated from teeth with endodontic failure and their antimicrobial susceptibility. Oral Microbiol Immunol 2003;18:100-3.

9. Gomes BP, Pinheiro ET, Gadê-Neto CR, Sousa EL, Ferraz CC, Zaia AA, et al. Microbiological examination of infected dental root canals. Oral Microbiol Immunol 2004;19:71-6.

10. Siqueira JF Jr, Rôças IN. PCR-based analysis of microorganisms associated with failed endodontic treatment. Oral Surg Oral Med Oral Pathol Oral Radiol Endod 2004;97:85-94.

11. Fouad AF, Zerella J, Barry J, Spångberg LS. Molecular detection of Enterococcus species in root canals of therapy-resistant endodontic infections. Oral Surg Oral Med Oral Pathol Oral Radiol Endod 2005;99:112-8.

12. Byström A, Sundqvist G. Bacteriologic evaluation of the efficacy of mechanical root canal instrumentation in endodontic therapy. Scand J Dent Res 1981;89:321-8.
13. Molander A, Reit C, Dahlén G. The antimicrobial effect of calcium hydroxide in root canals pretreated with $5 \%$ iodine potassium iodide. Endod Dent Traumatol 1999;15:205-9.

14. Möller AJ. Microbiological examination of root canals and periapical tissues of human teeth. Methodological studies. Odontol Tidskr 1966;74:1-380.

15. Zamany A, Safavi K, Spangberg LS. The effect of chlorhexidine as an endodontic disinfectant. Oral Surg Oral Med Oral Pathol Oral Radiol Endod 2003;96:578-81.

16. Martinho FC, Chiesa WM, Leite FR, Cirelli JA, Gomes BP. Antigenic activity of bacterial endodontic contents from primary root canal infection with periapical lesions against macrophage in the release of interleukin-1beta and tumor necrosis factor alpha. J Endod 2010;36:1467-74.

17. Siqueira JF Jr, Rôças IN. PCR methodology as a valuable tool for identification of endodontic pathogens. J Dent 2003;31:333-9.

18. Sathorn C, Parashos P, Messer HH. How useful is root canal culturing in predicting treatment outcome? J Endod 2007;33:220-5.

19. Peters LB, Wesselink PR. Periapical healing of endodontically treated teeth in one and two visits obturated in the presence or absence of detectable microorganisms. Int Endod J 2002;35:660-7.

20. Shuping GB, Ørstavik D, Sigurdsson A, Trope M. Reduction of intracanal bacteria using nickel-titanium rotary instrumentation and various medications. J Endod 2000;26:751-5.

21. McGurkin-Smith R, Trope M, Caplan D, Sigurdsson A. Reduction of intracanal bacteria using GT rotary Instrumentation, $5.25 \% \mathrm{NaOCl}$, EDTA, and $\mathrm{Ca}(\mathrm{OH})_{2}$. J Endod 2005;21:359-63.

22. Ørstavik D, Kerekes K, Molven O. Effects of extensive apical reaming and calcium hydroxide dressing on bacterial infection during treatment of apical periodontitis: A pilot study. Int Endod J 1991;24:1-7.

23. Sjögren U, Figdor D, Spangberg L, Sundqvist G. The antimicrobial effect of calcium hydroxide as a short-term intracanal dressing. Int Endod J 1991;24:119-25.

24. Wang CS, Arnold RR, Trope M, Teixeira FB. Clinical efficiency of $2 \%$ chlorhexidine gel in reducing intracanal bactéria. J Endod 2007;33:1283-9.

25. Waltimo T, Trope M, Haapasalo M, Orstavik D. Clinical efficacy of treatment procedures in endodontic infection control and one year follow-up of periapical healing. J Endod 2005;31:863- 6.

26. Siqueira JF, Paiva S, Rôcas IN. Reduction in the cultivable bacterial populations in infected root canals by a chlorhexidine-based antimicrobial protocol. J Endod 2007;33:541-7.

27. Zerella JA, Fouad AF, Spangberg LS. Effectiveness of a calcium hydroxide and chlorhexidine digluconate mixture as disinfectant during retreatment of failed endodontic cases. Oral Surg Oral Med Oral Pathol Oral Radiol Endod 2005;100:756-61.

28. Sathorn C, Parashos P, Messer HH. Effectiveness of single- versus multiple-visit endodontic treatment of teeth with apical periodontitis: A systematic review and meta-analysis. Int Endod J 2005;38:347-55.

29. Manzur A, González AM, Pozos A, Silva-Herzog D, Friedman S. Bacterial quantification in teeth with apical periodontitis related to instrumentation and different intracanal medications: A randomized clinical trial. J Endod 2007;33:114-8.

30. Saber Sel-D, El-Hady SA. Development of an intracanal mature Enterococcus faecalis biofilm and its susceptibility to some antimicrobial intracanal medications: An in vitro study. Eur J Dent 2012;6:43-50.

31. Ercan E, Dalli M, Dülgergil CT. In vitro assessment of the effectiveness of chlorhexidine gel and calcium hydroxide paste with chlorhexidine against Enterococcus faecalis and Candida albicans. Oral Surg Oral Med Oral Pathol Oral Radiol Endod 2006;102:27-31.

\begin{tabular}{|l|l|}
\hline \multicolumn{2}{|c|}{ Access this article online } \\
\hline Quick Response Code: & Website: \\
& www.eurjdent.com \\
\cline { 2 - 2 } & \\
\hline
\end{tabular}

